THE REVOLUTION OF

PETER THE GREAT

20 


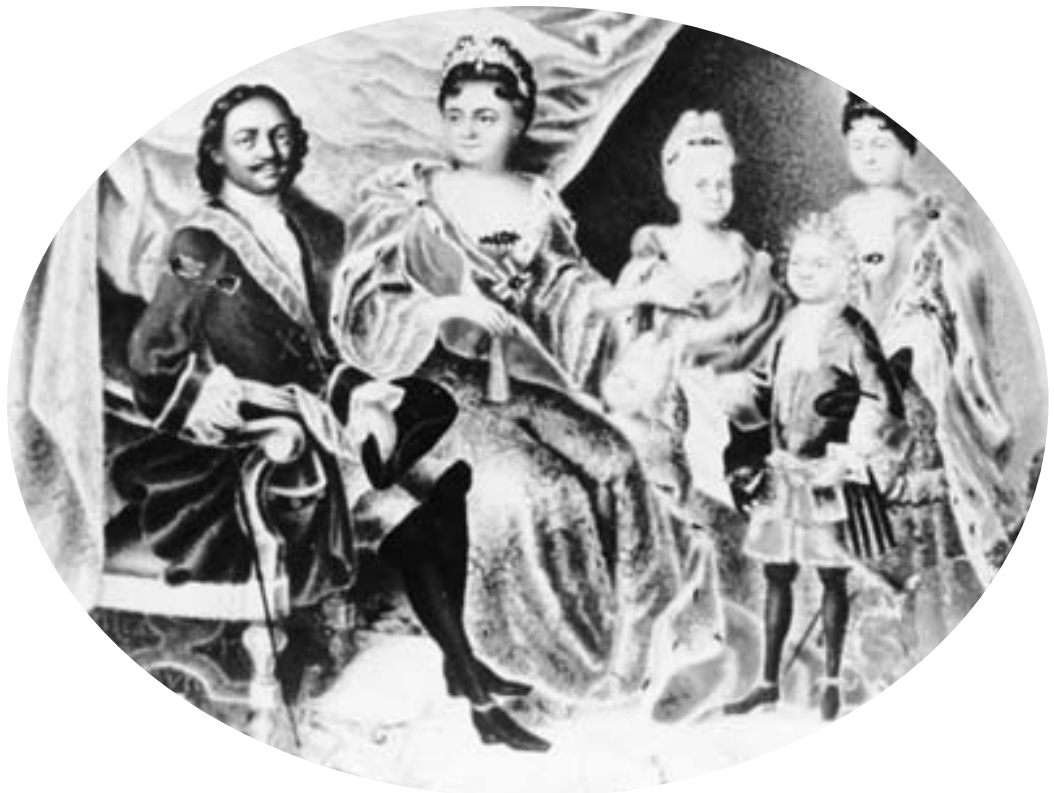

G. S. Musikiisky, Family Portrait of Peter I, 1720. Pictured with Peter are his wife Catherine, their daughters Anna, Elizabeth, and Natalia (at Catherine's knee), and the future Emperor Peter II, the tsar's grandson. 


\section{The Revolution of}

Peter the Great

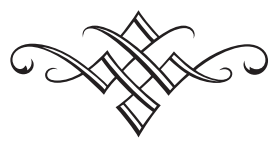

JAMES CRACRAFT

HARVARD UNIVERSITY PRESS

Cambridge, Massachusetts

London, England 
Copyright $(9) 2003$ by the President and Fellows of Harvard College All rights reserved

Printed in the United States of America

Frontispiece: G. S. Musikiisky, Family Portrait of Peter I, 1720.

Miniature in oil on enamel on copper base.

(Walters Art Gallery, Baltimore)

First Harvard University Press paperback edition, 2006

Library of Congress Cataloging-in-Publication Data

Cracraft, James.

The Revolution of Peter the Great / James Cracraft.

p. $\mathrm{cm}$.

Includes bibliographical references and index.

ISBN 0-674-0II96-I (cloth)

ISBN 0-674-0I984-9 (pbk.)

I. Peter I, Emperor of Russia, 1672-I725.

2. Russia-History—Peter I, I689-I725. I. Title.

$$
\begin{gathered}
\text { DKI3I.C73 } 2003 \\
947^{\prime} .05-\mathrm{dc} 21 \\
2003049917
\end{gathered}
$$

